\title{
What do parents learn by reading a DPT vaccine information form?
}

\author{
RONALD GOLD MD, GORDEAN L BJORNSON BSC MBA
}

\begin{abstract}
R GOLD, GL BJoRnson. What do parents learn by reading a DPT vaccine information form? Can J Infect Dis $1994 ; 5(2): 67-74$.
\end{abstract}

Овлестге: Information forms are commonly used to inform parents about childhood vaccination. This study assessed the knowledge of mothers about pertussis and pertussis vaccine before and after reading a form about diphtheria-pertussis-tetanus (DPT) vaccine.

DEsign: A test was administered to mothers before and after the first vaccination of their infant. By random allocation, one-half of the mothers received the form (study group) in addition to the routine counselling by a public health nurse given to the others (control group).

Setring: Public health immunization clinics in suburban Vancouver, British Columbia.

SubJEcts: One hundred and fifty-one mothers who were scheduled to bring their infant for the first DPT immunization were recruited, of whom 145 (96\%) completed the study.

INTERVENTIONS: A test consisting of 20 true/false questions was administered by telephone two weeks before and two weeks after the first DPT vaccination. Additional data about sources of vaccine information, maternal education, number of children and maternal age were obtained.

Outcome Measures: Mean scores and mean change in scores on test.

Results: The mean changes in scores between tests 1 and 2 in study and control groups were $+22.2 \%$ and $+6.9 \%$, respectively, on the disease-related questions $(\mathrm{P}<0.001)$ and $+14.6 \%$ and $+10.7 \%$, respectively, on the vaccine-related questions $(\mathrm{P}=0.16)$. The forms were considered to be very useful by the mothers and clearly enabled them to score higher on a test of their knowledge of pertussis and pertussis vaccine. Conclusions: Reading a DPT vaccine form enabled mothers to improve their knowledge of pertussis and pertussis vaccine.

Key Words: Diptheria-pertussis-tetanus, Informed consent, Pertussis, Pertussis vaccine, Vaccination

\section{Quels renseignements les parents tirent-ils de la lecture d'un feuillet sur le vaccin DCT?}

Овлестіғ : Les feuillets de renseignements sont souvent utilisés pour informer les parents au sujet de la vaccination de leurs enfants. Cette étude a cherché à évaluer les connaissances qu'acquièrent les mères au sujet de la coqueluche et de son vaccin, avant et après la lecture d'un feuillet qui traite du vaccin contre la diphtérie, la coqueluche et le tétanos (DCT).

MoDÈLE : Un test a été administré à des mères, avant et après la première vaccination de leur nourrisson. Au hasard, la moitié des mères ont reçu le feuillet (groupe d'étude) en plus des renseignements donnés habituellement par l'infirmière en santé publique aux autres mères (groupe témoin).

Contexte : Les cliniques d'immunisation en santé publique dans une banlieue de Vancouver, ColombieBritannique.

SuJETs : Cent cinquante et une mères ont eu un rendez-vous pour faire administrer à leur nourrisson sa

continued on next page

The Hospital for Sick Children, Department of Pediatrics, University of Toronto, Toronto, Ontario; and Vaccine Evaluation Center, BC's Children's Hospita!, University of British Columbia, Vancouver, British Columbia

Correspondence and reprints: Dr Ronald Gold, The Hospital for Sick Children, 555 University Avenue, Toronto, Ontario M5G

1X8. Telephone (416) 598-6273, Fax (416) 591-5032

Received for publication January 18, 1993. Accepted April 7, 1993 
première vaccination DCT. Cent quarante cinq d'entre elles (97\%) ont terminé l'étude.

InTERVENTION : Un test comportant 20 questions de type vrai ou faux a été administré par téléphone deux semaines avant, puis deux semaines après l'administration du premier vaccin DCT. D'autres données au sujet des sources d'information sur le vaccin, au sujet des renseignements donnés aux mères, du nombre d'enfants, et de l'âge de la mère ont été notés.

Paramètres Mesurés : Les scores moyens et la modification moyenne des scores obtenus au test.

RÉsultats : Les modifications moyennes entre les scores obtenus à la première et à la deuxième épreuve dans les groupes à l'étude et les groupes témoins ont été de $+22,2 \%$ et $+6,9 \%$ respectivement, pour ce qui est des questions portant sur la maladie $(\mathrm{P}<0,001)$ et de $+14,6 \%$ et $+10,7 \%$ respectivement pour ce qui est des questions sur le vaccin $(\mathrm{P}=0,16)$. Les feuillets ont été considérés très utiles par les mères et leur ont certes permis d'obtenir une note plus élevée au test qui visait à mesurer leurs connaissances sur la coqueluche et son vaccin.

ConcLusion : La lecture d'un feuillet sur le vaccin DCT a permis aux mères d'améliorer leurs connaissances sur la coqueluche et son vaccin.

$\mathrm{B}$ ECAUSE OF PUBLIC CONCERN ABOUT VACCINE SAFETY, major changes have occurred in immunization practice in North America. Before immunizing infants and children, it is now required by law in Ontario under the Health Promotion and Protection Act, and in the United States under the National Childhood Vaccine Injury Act of 1986, that parents be informed of the benefits and risks of childhood vaccines and of the risks of the disease to be prevented by vaccination $(1,2)$. The most common method of providing the required information to parents is by means of printed information forms, eg, Important Information for Parents produced by the United States Public Health Service. The forms used routinely in Alberta, and the Getting Your Shots booklet developed by the College of Physicians and Surgeons of Ontario and distributed by the Ontario Ministry of Health, were derived from the American forms (3). The Canadian Paediatric Society makes available to its members forms similar to those used in Ontario. New information forms have been developed in the United States as required under the National Childhood Vaccine Injury Act.

In spite of widespread use of such materials, no report of a study of their effectiveness in teaching parents about the diseases or vaccines was found in a search of Index Medicus for the period 1980 to August 1991 using the headings 'Diphtheria-tetanus-pertussis vaccine', 'Immunization', 'Informed consent', 'Pertussis vaccine', 'Vaccines' and 'Vaccination'. This study was undertaken to learn whether reading such a form before the first vaccination of their infant with diphtheria toxoid-pertussis vaccine-tetanus toxoid (DPT) improved the scores of mothers on a 20-item true/false test of their knowledge of pertussis and pertussis vaccine.

\section{MATERIALS AND METHODS}

This study was conducted in the Boundary and Central Fraser Valley Health Units, which serve predominantly Caucasian, middle class suburban areas adjoining Vancouver, British Columbia, during the fall and winter of 1989-90. In these areas, 40 to $50 \%$ of families use public health clinics rather than family physicians for immunization of their children. Lists of
TABLE 1

Twenty true/false questions on pertussis and pertussis vaccine

Question

1. Whooping cough is an infection caused by bacteria.

2. Whooping cough spreads easily from person to person.

3. Only babies get whooping cough.

4. Whooping cough causes a bad cough which lasts three to four days.

5. Babies with whooping cough often vomit and lose weight.

6. Babies with whooping cough always have to be admitted to hospital.

7. Whooping cough can cause convulsions in babies.

8. Whooping cough can cause brain damage in some babies.

9. Modern treatment cures whooping cough within one to two days.

10. Children can catch whooping cough more than once.

11. Whooping cough vaccine contains living germs.

12. Whooping cough vaccine causes fever in about one-half of babies.

13. The baby shot (or DPT) contains vaccines against whooping cough, tetanus (lockjaw) and diphtheria.

14. Some babies cry for many hours after whooping cough vaccine.

15. Whooping cough vaccine may cause a convulsion in some babies.

16. The vaccine often causes pain, redness and swelling in the arm or leg.

17. Acetaminophen (Tylenol, Tempra, Panadol) may reduce the side effects or reactions after whooping cough vaccine.

18. Only one injection is needed to prevent whooping cough.

19. The whooping cough vaccine provides protection for life.

20. The illness caused by whooping cough is much more serious than the potential side effects of the vaccine.

DPT Diphtheria-pertussis-tetanus vaccine

Answer
True
True
False
False
True
False
True
True
False
False
False
True
True
True
True


TABLE 2

\begin{tabular}{|c|c|c|}
\hline Characteristic & Control group & Study group \\
\hline Number & 74 & 77 \\
\hline Age (years, mean $\pm S D$ ) & $28.5 \pm 4.4$ & $29.2 \pm 4.0$ \\
\hline $\begin{array}{l}\text { Participation in any vaccine } \\
\text { study (\%) }\end{array}$ & 8.1 & 3.8 \\
\hline Years of school (Mean \pm SD) & $13.4 \pm 2.0$ & $13.2 \pm 2.1$ \\
\hline $\begin{array}{l}\text { Number }(\%) \text { with } 12 \text { or more } \\
\text { years of school }\end{array}$ & $67(91)$ & $67(87)$ \\
\hline $\begin{array}{l}\text { Number (\%) with college } \\
\text { degree }\end{array}$ & $12(16)$ & $14(18)$ \\
\hline Number (\%) with one child & $22(30)$ & $24(31)$ \\
\hline Number (\%) with two children & $34(46)$ & $33(43)$ \\
\hline $\begin{array}{l}\text { Number (\%) with three or more } \\
\text { children }\end{array}$ & $18(24)$ & $20(26)$ \\
\hline Number (\%) born in Canada & $69(93)$ & $75(97)$ \\
\hline
\end{tabular}

infants scheduled to receive their first DPT vaccination at the public health units were obtained by the study team. Mothers were sent a letter explaining the study and contacted by a study nurse by telephone to review the purpose of the study, answer questions and obtain verbal informed consent. Two weeks before the scheduled date of vaccination, mothers were telephoned and a test was administered, which contained 10 true/false questions concerning pertussis and 10 concerning pertussis vaccine (Table 1). Additional questions were asked concerning maternal age, place of birth, number of children, years of schooling and sources of information about vaccines. Half of the mothers were randomly allocated to receive the information form about DPT vaccine (Appendix 1), which was mailed to them with instructions to read it before the vaccination visit.

All parents were given verbal information about vaccines by the public health nurse at visits to the health units. At the time of this study, printed information forms were not provided at the immunization clinics. Approximately two weeks after vaccination, ie, four weeks after test 1 , the same test was administered by telephone to all of the mothers. The information form was based on the form used in Ontario, slightly modified to be applicable to British Columbia.

The effectiveness of the information form was assessed by comparing the mean scores and the mean changes in scores on each question in tests 1 and 2 of mothers who received the information form (study group) with scores of those who did not (control group). Differences in scores were compared by the paired $t$ test (Statview $\mathrm{SE}^{+}$Graphics for the MacIntosh). The 10 questions concerning the disease were analyzed separately from the 10 questions about pertussis vaccine. Correlations between scores on test 1 and maternal
TABLE 3

Sources of information about vaccination reported by 151 mothers

\begin{tabular}{|c|c|c|}
\hline \multirow[b]{2}{*}{$\begin{array}{l}\text { Source of information } \\
\text { (Reference) }\end{array}$} & \multicolumn{2}{|c|}{ Number $(\%)$ reporting use } \\
\hline & $\begin{array}{c}\text { Control group } \\
(n=74)\end{array}$ & $\begin{array}{l}\text { Study group } \\
(n=77)\end{array}$ \\
\hline Printed & $66(89)$ & $59(77)$ \\
\hline $\begin{array}{l}\text { Chatelaine's New Mother } \\
\text { (4) }\end{array}$ & $50(68)$ & $53(69)$ \\
\hline $\begin{array}{l}\text { Dr Spock's Baby \& Child } \\
\text { Care (5) }\end{array}$ & $22(30)$ & $19(25)$ \\
\hline $\begin{array}{l}\text { How to Raise a Healthy } \\
\text { Child (9) }\end{array}$ & $5(7)$ & $3(4)$ \\
\hline DPT: A Shot in the Dark (10) & $0(0)$ & $1(1)$ \\
\hline Television & $19(26)$ & $13(17)$ \\
\hline \multicolumn{3}{|l|}{ Person } \\
\hline Public health nurse & $54(73)$ & $55(71)$ \\
\hline Relatives & $42(56)$ & $32(41)$ \\
\hline Friends & $36(49)$ & $39(51)$ \\
\hline Family physician & $32(43)$ & $32(41)$ \\
\hline
\end{tabular}

age, number of children, years of schooling and use of various sources of information about vaccines were analyzed by multiple regression analysis (Statview $\mathrm{SE}^{+}$ Graphics for the MacIntosh).

This study was approved by the University of British Columbia Behavioral Sciences Screening Committee for Research and Other Studies Involving Human Subjects.

\section{RESULTS}

One hundred and fifty-one mothers were recruited into the study: 77 in the study group and 74 in the control group. Six mothers who completed the initial interview and test 1 did not complete the study: two (both in the study group) were contacted successfully but refused to take test 2 . The other four (one in the control group and three in the study group) could not be reached in spite of more than 10 telephone calls per household and were considered lost to follow-up. Of the 72 mothers in the study group who completed the second interview and test, 10 (13.9\%) reported that they had not read the information form provided by the study. Removing the nonreaders from the study group did not result in any significant change in group scores. Therefore, the results are presented in an intention-totreat form; namely, comparing the results of those who were with those who were not sent the form.

No significant differences between the study and control groups were found in terms of age, prior participation in vaccine studies, number of children, years of school or country of birth (Table 2). The average participant was 29.0 years old, had 13 years of schooling, two children and was born in Canada. The most commonly identified source of information about childhood vaccines was printed material: $83 \%$ of mothers reported 
TABLE 4

Scores of 151 mothers on test 1

\begin{tabular}{|c|c|}
\hline $\begin{array}{l}\text { Question } \\
\text { (See Table } 1 \text { for full text) }\end{array}$ & $\begin{array}{c}\text { Mean percentage } \\
\text { (95\% confidence } \\
\text { limits) with correct } \\
\text { answer }\end{array}$ \\
\hline 1. Pertussis is caused by bacteria. & $44(36-52)$ \\
\hline $\begin{array}{l}\text { 2. Pertussis spreads easily from person } \\
\text { to person. }\end{array}$ & $66(58-73)$ \\
\hline 3. Only babies get pertussis. & $87(81-92)$ \\
\hline $\begin{array}{l}\text { 4. Pertussis causes bad cough lasting } \\
\text { three to four days. }\end{array}$ & $40(32-48)$ \\
\hline 5. Babies often vomit and lose weight. & $52(44-60)$ \\
\hline 6. Babies are always hospitalized. & $44(36-52)$ \\
\hline 7. Pertussis can cause convulsions. & $57(49-65)$ \\
\hline 8. Pertussis can cause brain damage. & $48(40-56)$ \\
\hline $\begin{array}{l}\text { 9. Treatment cures pertussis in one to } \\
\text { two days. }\end{array}$ & $29(22-36)$ \\
\hline 10. Can get pertussis more than once. & $13(7-18)$ \\
\hline $\begin{array}{l}\text { 11. Pertussis vaccine contains living } \\
\text { germs. }\end{array}$ & $15(10-21)$ \\
\hline $\begin{array}{l}\text { 12. Pertussis vaccine causes fever in } \\
50 \% \text { of babies. }\end{array}$ & $68(61-76)$ \\
\hline $\begin{array}{l}\text { 13. Shot contains diphtheria, tetanus } \\
\text { and pertussis vaccines. }\end{array}$ & $86(81-92)$ \\
\hline $\begin{array}{l}\text { 14. Some babies cry for many hours } \\
\text { after pertussis vaccine. }\end{array}$ & $59(51-67)$ \\
\hline $\begin{array}{l}\text { 15. Pertussis vaccine can cause } \\
\text { convulsions. }\end{array}$ & $52(44-60)$ \\
\hline $\begin{array}{l}\text { 16. Pertussis vaccine often causes } \\
\text { pain, redness and swelling. }\end{array}$ & $85(79-91)$ \\
\hline $\begin{array}{l}\text { 17. Acetaminophen reduces some } \\
\text { side effects. }\end{array}$ & $92(88-96)$ \\
\hline $\begin{array}{l}\text { 18. Only one injection of pertussis } \\
\text { vaccine is needed. }\end{array}$ & $63(55-71)$ \\
\hline 19. Pertussis vaccine protects for life. & $27(19-34)$ \\
\hline $\begin{array}{l}\text { 20. The disease is much worse than } \\
\text { reactions to vaccine. }\end{array}$ & $91(86-95)$ \\
\hline $\begin{array}{l}\text { Mean score on } 10 \text { disease-related } \\
\text { questions. }\end{array}$ & $48(41-54)^{*}$ \\
\hline $\begin{array}{l}\text { Mean score on } 10 \text { vaccine-related } \\
\text { questions. }\end{array}$ & $64(59-69)^{*}$ \\
\hline
\end{tabular}

$.99 .9 \%$ confidence limits of the mean

reading about vaccines. Chatelaine's New Mother (4) was read by $67 \%$ of mothers. This magazine contains information on the first year of life and is provided free to new mothers at most Canadian hospitals. It contains a four-page article on routine childhood vaccines that is updated and reviewed annually by one of the authors. Only $25 \%$ of mothers reported reading $\mathrm{Dr}$ Spock's Baby \& Child Care (5) or other child care guides for information about vaccines. A public health nurse was used as a source of information by $72 \%$ of mothers, which is to be expected since the study mothers used the local health unit for immunization of their children rather than their family doctor (Table 3), and many had been visited by such a nurse during the first month after delivering their baby. The family physician, rela- tives and friends were used for information by many mothers, but only 20\% reported seeing any television shows about vaccination.

The mean age of the infants at vaccination was 2.3 months. The mean interval between administration of tests 1 and 2 was 4.4 weeks.

No significant differences in scores on any question in test 1 were found between the two groups; the combined results are presented in Table 4 . The mean score on test 1 was $55.8 \%$. The scores were significantly lower on the 10 disease-related questions than on the 10 vaccine questions: $48 \%$ versus $64 \%(\mathrm{P}<0.01)$. Such results suggest a poor level of knowledge about pertussis in this sample of well-educated mothers living in suburban Vancouver. The mean number of years of schooling of these mothers (13.3 years) was more than one year higher than the Canadian average ( 12.2 years) (6). The majority of mothers did not know that pertussis is a bacterial infection characterized by prolonged cough, often associated with vomiting and weight loss. Most mothers did not know that pertussis can cause brain damage and very few knew that antibiotics are ineffective in treating the disease or that immunity after disease is long lasting. Most mothers were familiar with the common reactions to DPT vaccine, but more than a third thought that only one dose of vaccine was required, three-quarters that vaccine provided lifelong protection and 85\% that DPT contains live germs.

Multiple regression analysis indicated that mothers with two or more children scored significantly higher on test 1 than did those with only one child on both the disease-related (partial $\mathrm{F}=8.655, \mathrm{P}=0.0038$ ) and vaccine-related questions (partial $\mathrm{F}=8.844, \mathrm{P}=0.0035$ ), but maternal age, years of schooling, or use of printed or other sources of information about vaccines had no significant correlation with the scores. The mean scores on test 1 of mothers with only one child and of those with two or more children were $39.1 \%$ versus $51.6 \%$ on the 10 disease-related questions, respectively, and $56.3 \%$ versus $67.1 \%$ on the 10 vaccine-related questions.

Mothers in the study group showed significantly greater improvement in their scores on disease-related questions on test 2 than did those in the control group (Table 5).

The total mean score on the 10 disease-related questions increased by $22.2 \%$ in the study group, compared with $6.9 \%$ in the control group $(\mathrm{P}<0.0001)$. Mothers in the study group scored better particularly on questions related to disease severity and contagiousness. The mean changes in score were higher in the study group than in the control group on all 10 questions (sign test, $\mathrm{P}<0.05)$.

The information form had less effect on improving the scores on the 10 vaccine-related questions, primarily because the scores were higher to begin with. The study group increased the total score by $14.6 \%$ com- 


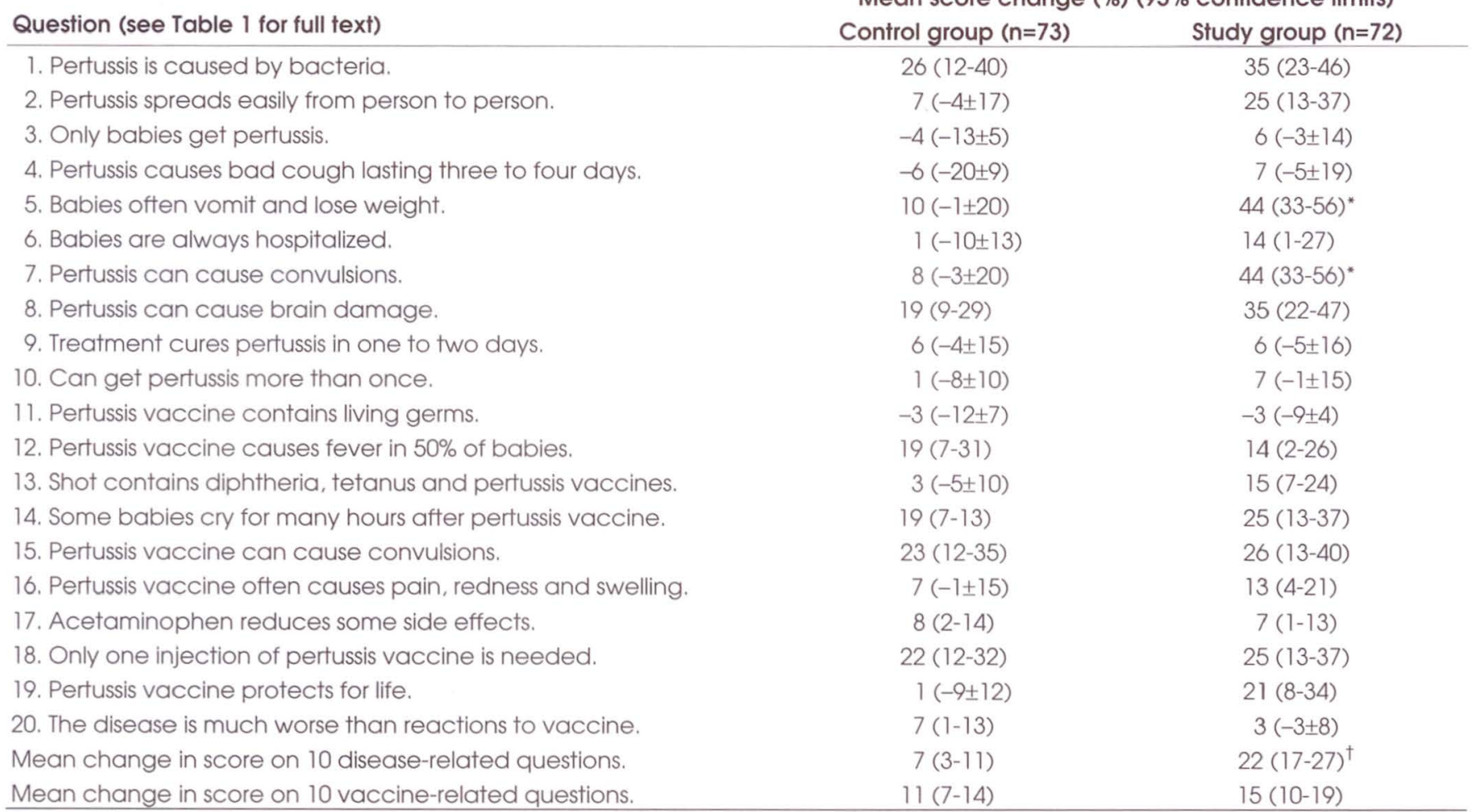
$P<0.0001 ;{ }^{\dagger} P<0.001$

pared with $10.7 \%$ for the control group $(\mathrm{P}=0.16)$. The only statistically significant differences were on the questions on vaccine composition $(\mathrm{P}=0.032)$ and on the duration of vaccine-related immunity $(\mathrm{P}=0.022)$. However, the study group showed more improvement on seven of the 10 vaccine-related questions (sign test, $0.05>\mathrm{P}<0.1)$.

There was a correlation between the scores on test 1 and the percentage increase in score between tests 1 and 2, which may explain the lack of a statistically significant improvement in the set of vaccine-related questions. On questions on which mothers had high scores $(70 \%$ or higher) in test 1 , the increases in test 2 were $5 \%$ in the control group and $9 \%$ in the study group $(P<0.2)$. Thus, it was difficult to detect a significant change in questions to which most mothers already knew the correct answer. On questions in which the initial scores were less than $70 \%$, the increases between the two tests were $15 \%$ in the control group and $35 \%$ in the study group $(\mathrm{P} \leq 0.01)$. All of the questions with high initial scores were vaccine-related questions (six in the control and five in the study group). Failure to detect a significant increase in scores in vaccine-related questions may have occurred because the mothers scored very high $(70 \%$ or higher) on five to six of these questions, and the sample size was too small to exclude a type II error.
Of 62 mothers who stated that they had read the form, $97 \%$ reported it to be useful in answering their questions about pertussis and the vaccine, and helped them in deciding about vaccination of their child. This high a level of acceptance for an information form is noteworthy and suggests that the mothers were very interested in learning more about the vaccines their infants were to receive.

\section{DISCUSSION}

The results of this study indicate that this sample of well-educated mothers knew relatively little about pertussis and had some major gaps in their knowledge about pertussis vaccine. As the parents received the form seven to 10 days before the immunization visit, they had more time to seek answers to questions raised by reading it. Thus, any improvements in test scores may have been larger than in the situation in which the parent is given the information form at the first immunization visit. However, where such forms are used by primary care physicians and immunization clinics, they are frequently given to parents shortly after delivery of a baby or at the first well-child checkup at two to six weeks of age. The fact that mothers with two or more children scored significantly higher than mothers with one child suggests that prior involvement with the process of vaccination in the public health clinic was an 
important learning experience. The lack of correlation between use of books and magazines on child-rearing and scores on test 1 suggests that such sources of information do not provide adequate coverage of vaccine-preventable infections or of vaccination.

The results of this study have implications for those involved in writing vaccine information forms for parents, as well as the authors of books for parents on child-rearing. If such forms are to be useful in helping parents make informed decisions concerning vaccination of their children, then the knowledge base of parents must be assessed in order to know what facts to include in the forms. The issue of what parents need to know to make informed decisions about vaccination must be addressed. The major concerns expressed by parents relate to vaccine safety, with vaccine efficacy and disease severity being less important (7). However, it is not yet clear how best to inform parents about risks. A recent study by Freeman and Bass (8) found that $61 \%$ of mothers preferred risk statements about a hypothetical new vaccine to be expressed in numerical language, while $73 \%$ of physicians predicted that their patients would prefer non-numeric language.

The objectives of such forms should be to provide parents with basic knowledge about the diseases and vaccines in question. Parents should have an understanding of the cause, frequency and course of each disease, the frequency and severity of complications, and the availability and effectiveness of treatment. They should also have knowledge of how vaccines work and are administered, the schedule of vaccination, effectiveness of vaccines in preventing disease, and frequency and severity of adverse events associated with vaccination. This study addressed only a very limited, homogeneous sample of Canadian-born parents residing in suburban Vancouver, and its results cannot be generalized to parents of different cultural, ethnic or educational status. Moreover, only one disease, pertussis, and one vaccine, DPT, were studied. The results do suggest that a one-page information form can provide sufficient information to result in learning of facts about pertussis and pertussis vaccine, as measured by significant improvement in scores on a simple true/false set of 20 questions. The major unanswered questions facing the designers of information forms were not addressed by this type of study, namely: how much information is required to enable a parent to make an informed decision about vaccination; when such information should be given to parents; what the best methods of providing the information are; how to tailor the messages for groups of parents of differing cultural, ethnic and/or educational backgrounds; and how to monitor the effectiveness of such educational efforts.

\section{APPENDIX 1 \\ INFORMATION FORM FOR PARENTS*}

Vaccines (or baby shots) are the best way to keep from getting many severe infections. The Canadian Paediatric Society and the National Advisory Committee on Immunization strongly recommend routine immunization of all children.

DPT vaccine protects children and adults against diphtheria (D), pertussis (P, also known as whooping cough) and tetanus (T). DPT vaccine is given as a number of injections to infants and young children. Children should get three injections in the first year and a fourth injection when they are 18 months old. A fifth injection or booster is given before they enter school at four to six years of age. Additional boosters are given every 10 years for diphtheria and tetanus in older children and adults. Pertussis vaccine is not given after the seventh birthday.

DPT vaccine may have some side effects. The risk of getting the side effects is much less than the risk of the diseases prevented by the vaccine. This information sheet outlines the reasons for getting the DPT vaccine. It also lists the important side effects of the vaccine that sometimes occur. If you have any questions or concerns, please talk to the public health nurse or your doctor.

\section{WHY IS DPT VACCINE IMPORTANT?}

DPT vaccine is important because it is the best way to prevent diphtheria, pertussis and tetanus. It is a threein-one vaccine that contains vaccines against diphtheria, pertussis and tetanus. Each of these vaccines is also available separately if needed. Here is some information about these diseases.

Diphtheria: Diphtheria is a very severe disease. One in 10 people who get it dies. Diphtheria can cause an infection in the nose and throat which blocks breathing. It can also be complicated by heart failure and nerve damage. Sometimes diphtheria causes skin or ear infections. Diphtheria is rare in Canada today because almost all children are vaccinated. It is common in other parts of the world where the vaccine is not used. Diphtheria vaccine (also called diphtheria toxoid) protects most people who are vaccinated. After a series of injections in childhood, boosters are required every 10 years to stay protected.

Pertussis (whooping cough): Pertussis is also called whooping cough. It is very contagious and spreads easily from person to person. Pertussis can cause severe coughing spells. The child or adult coughs and coughs without being able to stop. The illness can last for 10 weeks or more. Most infants also have vomiting and lose weight. Pertussis can cause breathing problems, pneumonia, convulsions, brain damage and death. Complications occur most often in infants less 
than one year old. Over 2000 cases occur every year in Canada.

Three doses of pertussis vaccine prevent pertussis in eight out of 10 children. Sometimes children who have gotten the vaccine still get whooping cough. When this happens, the illness is usually mild and complications are rare.

For many years, there has been controversy about whether the pertussis vaccine causes brain damage. The question has been studied closely for about 20 years. Leading experts have reviewed these studies and found that there is no evidence that the pertussis vaccine causes brain damage.

Protection against pertussis wears off in later childhood so that teenagers and adults can get pertussis even if they were fully vaccinated. The disease is much milder in older children and adults than in infants, and complications are rare.

Tetanus: Tetanus is also called lockjaw. Although the germs that cause tetanus are very common in soil and dust everywhere, the disease is very rare in Canada because almost everyone has been vaccinated. It is very common in parts of the world where the vaccine is not used. Tetanus is a disease people get after injuries or cuts. Tetanus kills six out of every 10 people who get it. Some people who get tetanus had such minor cuts or wounds that they did not see a doctor. Tetanus vaccine (also called tetanus toxoid) protects almost everyone who gets at least three injections. Regular booster injections are necessary every 10 years after childhood to stay protected. The vaccine is not needed after every cut or injury if regular boosters have been given.

\section{WHAT ARE THE SIDE EFFECTS OF DPT VACCINE?}

About half of the children who get DPT vaccine have minor side effects. These side effects include:

- Redness, swelling and pain where the injection was given. Sometimes a lump stays at the injection site for a few weeks.

- Fever of less than $40^{\circ} \mathrm{C}\left(104^{\circ} \mathrm{F}\right)$.

- Fussiness, irritability, crying, loss of appetite or vomiting.

Fever and other minor reactions can be reduced by giving the child acetaminophen (Tempra, Tylenol, Panadol, etc) in the doctor's office when the needle is given and repeated twice more at four-hour intervals. Ask your doctor or the public health nurse about this. More severe reactions are rare. They occur within two to three days after getting the vaccine. Severe side effects include:

- Very high fever, over $40.5^{\circ} \mathrm{C}$ (over $105^{\circ} \mathrm{F}$ ) (once in 330 injections).

- Crying or screaming for more than $3 \mathrm{~h}$ (once in 100 injections).
- Convulsions (once in 1800 injections).

- Collapse in which the child is very pale and quiet and does not respond normally (once in 1800 injections).

- Allergic reactions such as hives, wheezing, difficulty breathing, swelling of the face or mouth (extremely rare).

The benefits of the DPT vaccine are much greater than the risk of the side effects. Almost everyone who gets the vaccine is protected from diphtheria, tetanus and pertussis.

\section{WHEN SHOULD I CALL MY DOCTOR OR PUBLIC HEALTH NURSE?}

It is wise to keep a close watch on anyone after they have had a vaccine. Although severe reactions are rare, call your doctor right away if you notice any of the following within three days of the vaccination:

- Convulsions;

- A very high fever (over $40^{\circ} \mathrm{C}$ or $104^{\circ} \mathrm{F}$ );

- Crying for more than $3 \mathrm{~h}$;

- Unusual behaviour;

- Very pale colour and very sleepy;

- Allergic reactions such as hives, wheezing, difficulty breathing, swelling of the face or mouth:

- Any other serious abnormality.

WHO SHOULD NOT HAVE THE DPT VACCINE?

Some children should not have the DPT vaccine. Who?

- Anyone who has had a severe reaction to the DPT vaccine before.

- Anyone who has a fever or infection worse than a cold.

- Anyone who is allergic to antibiotics called neomycin or streptomycin.

If you think your child is in one of these groups, speak to your doctor or public health nurse.

\section{QUESTIONS}

If you have any questions about the DPT vaccine, check with your family doctor, the local health department or the public health nurse.

ACKNOWLEDGEMENTS: We thank: Drs William Meekison and Roland Guasparini for allowing access to the children in their health units; Terri Arcand, Diane Mountain and the nursing staff of The Associated Study Center, Vancouver, British Columbia, for conducting the field aspects of the study; Therèse Soong of the Vaccine Evaluation Center, BC's Children's Hospital, Vancouver, BC, for data management; and Dr David W Scheifele (Vaccine Evaluation Center) for reviewing the manuscript. This study was supported in part by a grant from Connaught Laboratories Ltd, Willowdale, Ontario. 


\section{REFERENCES}

1. College of Physicians and Surgeons of Ontario. Immunization: Benefits, Risks, and Reportable Events. A Guide for Ontario Physicians. Toronto: College of Physicians and Surgeons of Ontario, 1990:1-15.

2. Committee on Infectious Diseases. Informed consent. In: Peter G, ed. Report of the Committee on Infectious Diseases. Elk Grove Village: American Academy of Pediatrics, 1991:9-10.

3. College of Physicians and Surgeons of Ontario. Getting Your Shots. Toronto: Queen's Printer for Ontario, 1989.

4. Draycott A, ed. Chatelaine's New Mother. Toronto: Maclean Hunter Ltd, 1989:38-42.

5. Spock BM, Rothenberg MB. Dr Spock's Baby \& Child
Care, 5th edn. NY: Pocket Books Inc, 1985:230-6,587-96.

6. Statistics Canada. Canada Yearbook 1990. Ottawa: Ministry of Service and Supply, 1989:4-2.

7. Shawn DH, Gold R. Survey of parents' attitudes to the recommended Haemophilus influenzae type $\mathrm{b}$ vaccine program. Can Med Assoc J 1987;136:1038-40.

8. Freeman TR, Bass MJ. Risk language preferred by mothers in considering a hypothetical new vaccine. Can Med Assoc J 1992;147:1013-7.

9. Mendelsohn R. How to Raise a Healthy Child ... in Spite of Your Doctor. Chicago: Contemporary Books Inc, 1984:209-30.

10. Coulter HL, Fisher BL. DPT: A Shot in the Dark. New York: Warner Books, 1985:470. 


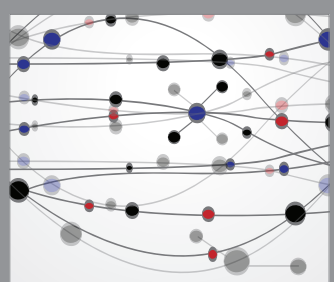

The Scientific World Journal
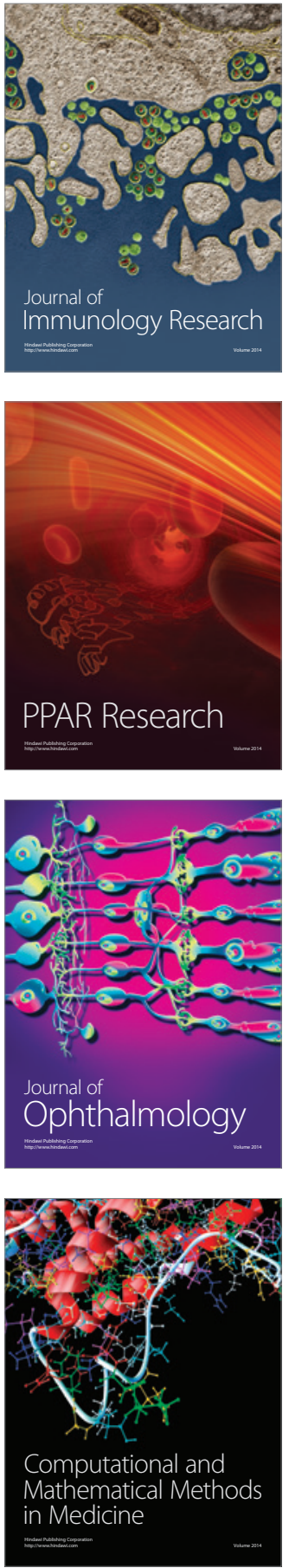

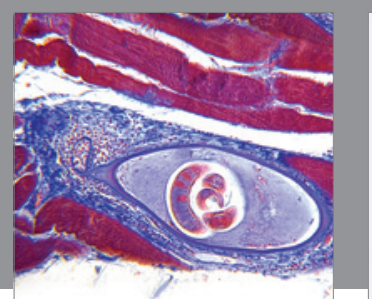

Gastroenterology Research and Practice

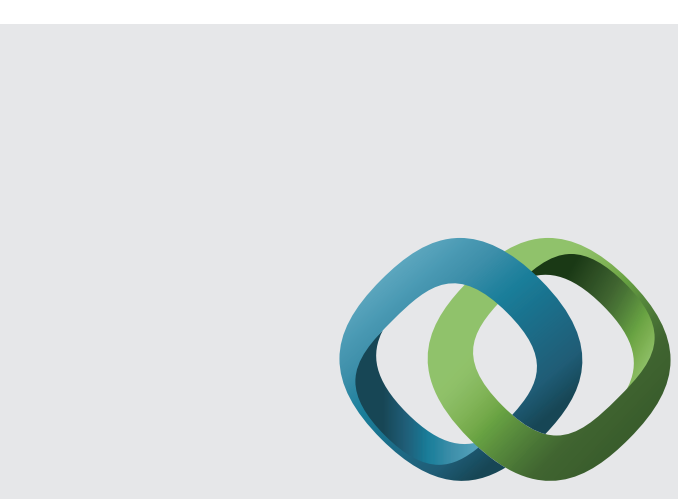

\section{Hindawi}

Submit your manuscripts at

http://www.hindawi.com
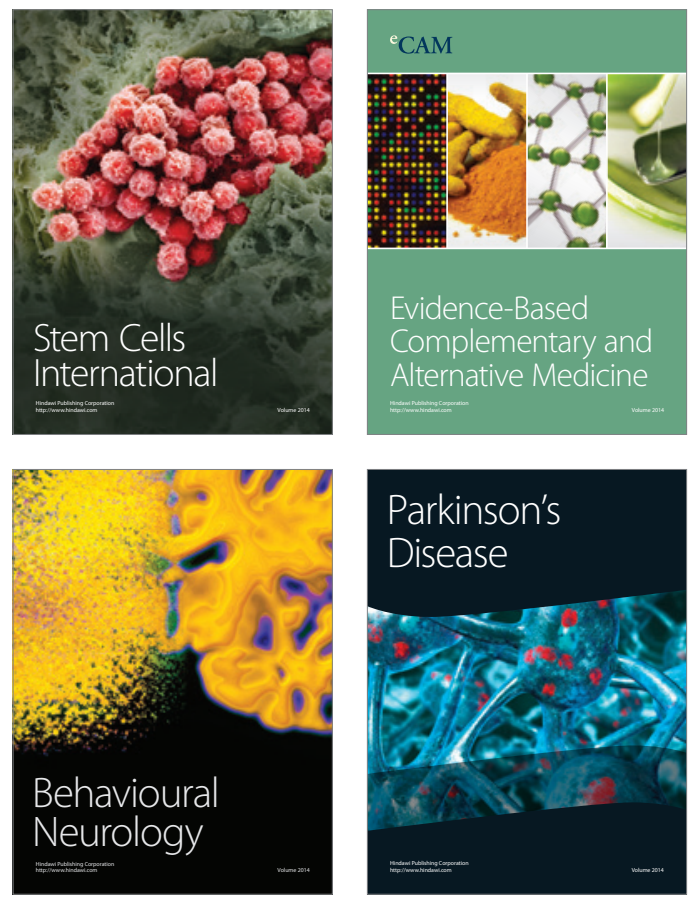
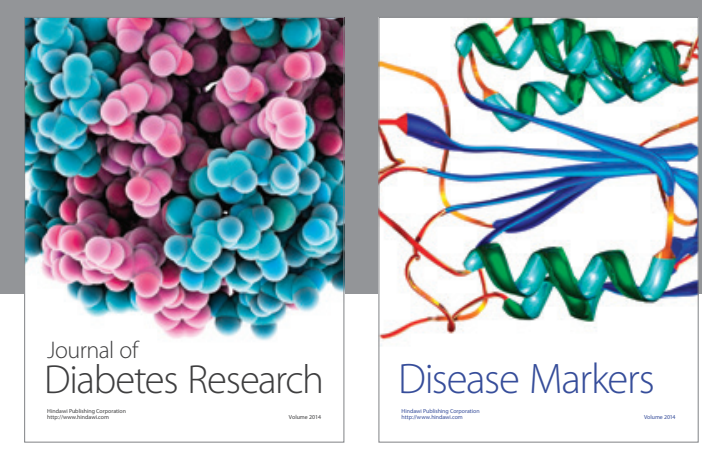

Disease Markers
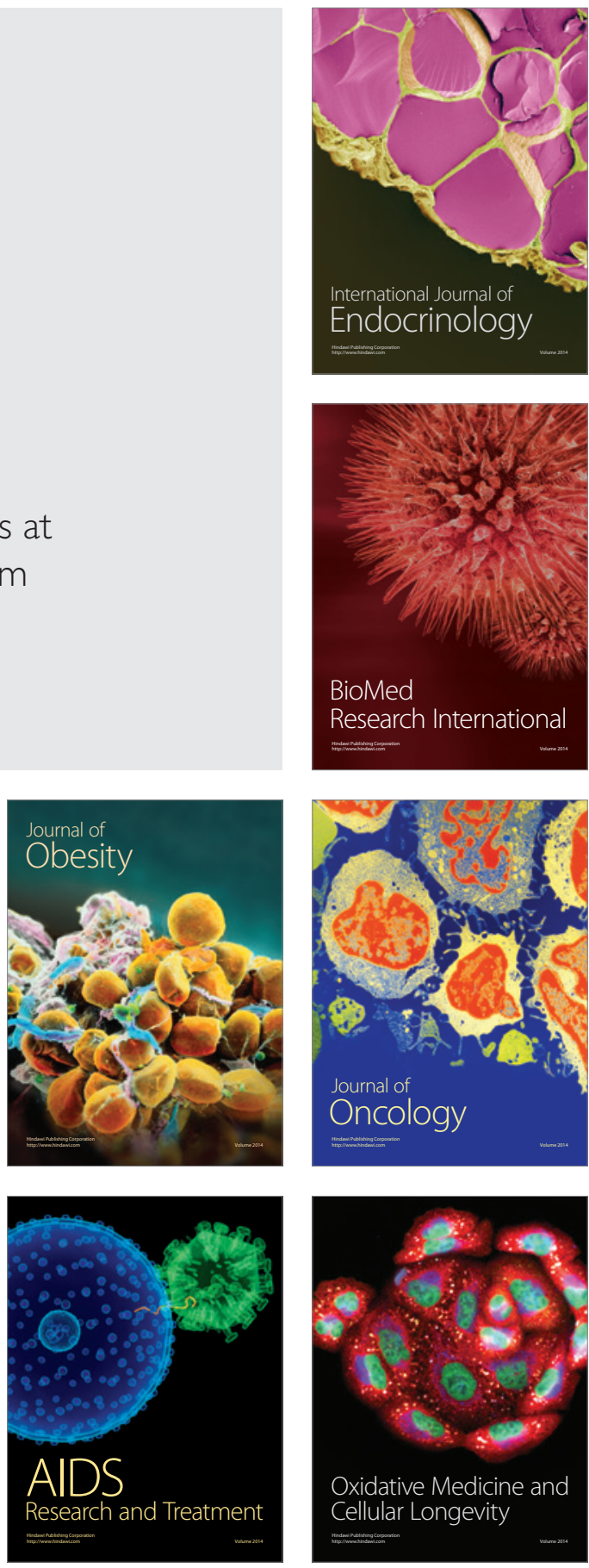